Of the three theories of pensions-gratuity, unilateral contract, and deferred wage-either the unilateral contract or deferred wage theory allows recovery by the employee who has completed his term of service under the plan, while the gratuity theory recognizes no obligation whatsoever by the employer. In the earlier period before retirement, the unilateral contract theory is similar in effect to the gratuity theory. The deferred wage theory, on the other hand, while preserving the emphasis which the unilateral contract theory places upon continuity of service, affords recovery at all stages to the employee who has been promised a pension for remaining with his employer as long as he is able to do so.

\title{
THE SINGLE RENTAL AS A "TRADE OR BUSINESS" UNDER THE INTERNAI REVENUE CODE
}

The question of whether a taxpayer who owns and rents a single piece of real property is engaged in a "trade or business" has produced two adverse lines of authority highlighted by a recent conflict between circuits. One line of authority ${ }^{1}$ indicates that bare ownership of rented property is not a trade or business; that the trade or business status results from some degree of activity carried on by the taxpayer in operating and managing the property. The other view ${ }^{2}$ holds that the trade or business status results from a mere renting of the property, without inquiry into the extent of the taxpayer's rental activities. It is the purpose of this comment to compare these opposing views, examine the historical reasons for the conflict, and suggest a possible solution.

This issue-whether such rental activities constitute a trade or businesshas significance in the application of several sections ${ }^{3}$ of the Internal Revenue Code of $1954 .{ }^{4}$ Usually, but not always, it is to the taxpayer's advantage to be in a trade or business.

\footnotetext{
1 The second circuit (Grier v. United States, 218 F. 2d 603 [C.A. 2d, 1955], discussed at page 119 infra) and sixth circuit (Fackler v. Comm'r, 133 F. 2d 509 [C.A. 6th, 1943], discussed at page 113 infra).

${ }^{2}$ The Tax Court (John D. Fackler, 45 B.T.A. 708 [1941], discussed at page 113 infra, and Leland Hazard, 7 T.C. 372 [1946], discussed at page 117 infra) and the seventh circuit (Reiner v. United States, 222 F. 2d 770 [C.A. 7th, 1955], discussed at page 119 infra).

"The meaning of the words "trade or business" as used in some sections is not significant for the "small" landlord. Operating expenses and depreciation are deductible if the rental operation is either a "trade or business" (expenses $\$ 162$; depreciation $\$ 167$ ) or "production of income" (expenses $\S 212$; depreciation $\$ 167$ ). This may be compared to the provision on losses $(\$ 165)$, which are deductible if sustained in either a "trade or business" or a "transaction entered into for profit." In each instance the alternative category is easier to reach so litigation usually centers about it and doesn't reach the trade or business question. For this taxpayer the bad debts provision (Int. Rev. Code $\$ 166$ ) is also of little concern.
}

"Title 26 U.S.C.A. (1955), hereafter referred to as "the Code." 
The issue arises most frequently in the classification ${ }^{5}$ of losses on the sale of rental property. A loss on the sale of trade or business property is almost always an ordinary loss. ${ }^{6}$ With nontrade or business property, however, a loss on sale results in a capital loss ${ }^{7}$-less desirable than an ordinary loss under most circumstances. ${ }^{8}$

Losses from the sale or operation of trade or business property are subject to favorable carryover privileges. ${ }^{9}$ But as to nontrade or business property, an operating loss is not subject to carryover,,$^{10}$ and a loss on sale is subject to the limited deductibility incident to a capital loss carryover. ${ }^{11}$

The taxpayer-landlord in a trade or business is at a significant disadvantage ${ }^{12}$ only in the classification of gains on the sale of rental property. The sale

${ }^{5}$ As to the deductibility of losses-ordinary or capital-consult note 3 supra.

- The exception relates to trade or business property held over six months, and part of a combination of gains and losses under Section 1231 which results in an excess of gains. Consult note 13 infra.

' Capital assets are defined as all of a taxpayer's property, with certain enumerated exceptions which include: "property, used in his trade or business, of a character which is subject to the allowance for depreciation ... or real property used in his trade or business." Int. Rev. Code $\$ 1221$.

${ }^{8} \mathrm{An}$ ordinary loss is deductible in full from ordinary income in the year sustained (Int. Rev. Code $\S 165$ ), and subject to the most favorable carryover privileges (see note 9 infra). A capital loss may be deducted from ordinary income only to the extent of $\$ 1,000$ per year (Int. Rev. Code $\$ 1211$ ), and the provisions for its carryover are subject to restrictions and disadvantages (see note 11 infra).

${ }^{\circ}$ Operating losses of a trade or business (ordinary losses) are eligible to be offset in full, first against the ordinary income and then against the capital gains, of the two preceding and five subsequent tax years (Int. Rev. Code $\$ 172$ ). Under a new provision in the 1954 Code, losses on sales of trade or business property are eligible for the same carryover (Ibid.). The 1939 Code limited the carryover privilege to losses "attributable to the operation of a trade or business regularly carried on by the taxpayer. . . " (Int. Rev. Code of 1939 $\S 122$ ). A loss on the sale of property used in the trade or business was not felt to be included since "The loss did not arise or result from the operation of such business but upon the disposition of assets used therein." I.T. 3711, 1945 Cum. Bull. 162, 164; Joseph Sic, 10 T.C. 1096 (1948), aff'd 177 F. 2d 649 (C.A. 8th, 1949).

${ }^{10}$ Int. Rev. Code $\$ 172$.

11 For purposes of carryover, as well as in the year of loss, a capital loss may offset ordinary income only to the extent of $\$ 1,000$ per year (Int. Rev. Code $\$ 1211$ ). Furthermore, a capital loss must be offset first against capital gains which, if they are long term capital gains, are subject to a more favorable rate of tax (Ibid., at $\$ \$ 1201,1202$ ). An ordinary loss, sure to be offset first against income taxed at the higher rates, is clearly more desirable. Another limitation is that capital losses may be carried over only to the five succeeding tax years (Ibid., at $\$ 1212$ ).

${ }^{12}$ Another disadvantage of less importance relates to carryover. The Code ( $(172)$ provides that nonbusiness deductions (such as medical expenses, contributions, etc.) are not subject to carryover. It further provides that only the excess of business losses over business gains can be carried over. Therefore, if a taxpayer's rental activities are a trade or business, his rental gains (profits) may be completely offset by another business loss. Since his nonbusiness deductions could not be carried over, they would be irreclaimable. On the other hand, if the rental activities were not a trade or business, rental gains would first offset nonbusiness deductions, leaving the business loss eligible for carryover. Another disadvantage is discussed in note 13 infra. 
of trade or business property gives rise to a "section 1231 gain," which is a capital gain only under certain circumstances. ${ }^{13} \mathrm{~A}$ gain on the sale of nontrade or business property, on the other hand, is always a capital gain. ${ }^{14}$

The courts apparently agree that the meaning of the words "trade or business" is uniform throughout the Code provisions here considered, ${ }^{15}$ but disagreement exists over what that meaning is. The two methods of approach were set forth nicely in a single case, John D. Fackler. ${ }^{16}$ The taxpayer there had owned a lease on a business building which he rented to various tenants. The issue was whether a gain on the sale of this lease was a capital or ordinary gain. ${ }^{17}$ Arguing for an ordinary gain, the Commissioner prevailed in his contention that the lease was trade or business property. The Board of Tax Appeals, predecessor of the Tax Court, laid down the rule in this manner:

[W] here the owner of depreciable property devotes it to rental purposes and exclusively to the production of taxable income, the property is used by him in a trade or business. ... ${ }^{18}$

This theory, that renting is automatically a trade or business, was not followed on appeal. Although the sixth circuit affirmed the decision, in doing so it examined the extent of the taxpayer's rental activities, stating:

The management of the property necessarily involved alterations and repairs. ... It was also necessary to furnish elevator service, heat, light and water which required

\footnotetext{
${ }^{23}$ Section 1231 provides that gains and losses from sale or exchange of real or personal property used in the trade or business and held over six months will be lumped together with gains and losses from compulsory or involuntary conversion of such property and capital assets held over six months. If the excess is gain, it is a long term capital gain. If the excess is loss, it is an ordinary loss. In this provision lies another slight disadvantage for the taxpayer in a trade or business. If a taxpayer already has a loss which would qualify as a Section 1231 loss, he will prefer a capital gain on the sale of rental property. That would leave undiminished the Section 1231 loss, which then offsets ordinary income on which the rate of tax is much higher than that paid on capital gains. Otherwise, a moderately taxed gain would be offset by a loss which might otherwise have reduced the higher-taxed ordinary income.
}

Is Int. Rev. Code $\$ 1221$. The desirability of capital gains rests in the favorable rate of tax (Ibid., $\$ 1201,1202$ ) applicable to such gains when the asset sold was held over six months.

${ }^{15}$ No court has made an explicit distinction between a "trade or business" authority under one section of the Code and another under a different section. On the contrary, the courts cite indiscriminately any case having to do with "trade or business" whether under Section 1221, 1231, 165 or 162 . Compare the distinction suggested to the court in Reiner v. United States, page 119 infra.

${ }^{16} 45$ B.T.A. 708 (1941), aff'd 133 F. 2d 509 (C.A. 6th, 1943).

${ }^{17}$ Section 1231 of the Code which makes possible capital gains treatment for gains on sale of trade or business property (note 13 supra), was not part of the Code until Section 151 of the Revenue Act of 1942, 56 Stat. 798 (1942).

${ }^{28} 45$ B.T.A. 708, 714 (1941). 
regular and continuous activity and the employment of labor, the buying of material and many other things which come within the definition of business. ${ }^{19}$

The sixth circuit was apparently of the view that the trade or business status was not automatic on renting, but required some degree of subsequent activities in operation and management. The Board of Tax Appeals and its successor the Tax Court have, however, continued to follow the mechanical rule that mere renting is a trade or business, ${ }^{20}$ and have even expanded it to hold that the category sometimes might be reached prior to renting. ${ }^{21}$

This continuing Tax Court position is hard to justify in view of the history of the phrase "trade or business." Prior to the Revenue Act of $1942,{ }^{22}$ a taxpayer was allowed deductions for expenses and depreciation only if engaged in a trade or business. ${ }^{23}$ Therefore if a landlord with a single rental dwelling was not in a trade or business he would be taxed on his gross rentals. In view of the unfairness of such a result it is not surprising that the Board of Tax Appeals in the Fackler case ${ }^{24}$ and others like it ${ }^{25}$ found taxpayer-landlords to be in a trade or business, even without attention to the extent of their rental activities.

But this line of decisions should have been re-evaluated after the Supreme Court's decision in Higgins v. Commissioner. ${ }^{26}$ That case held that a taxpayer occupied full time in the management of his securities (worth over 35 million

\footnotetext{
${ }^{19}$ Fackler v. Comm'r, 133 F. 2d 509, 512 (C.A. 6th, 1943). The court relied on Comm'r v. Boeing, 106 F. 2d 305 (C.A. 9th, 1939), cert. denied 308 U.S. 619 (1939), where the court denied capital gains treatment to a taxpayer who employed a logging company to cut his timber and deliver it to the tidewater to be sold. He was found to be in a "trade or business." The court there held the rule to be: "the facts necessary to create the status of one engaged in a trade or business revolve largely around the frequency or continuity of the transactions claimed to result in a 'business' status." Tbid., at 309.

${ }^{20}$ E.g., Quincy A. S. McKean, 6 T.C. 757 (1946) (capital or ordinary loss question); Sam Weingart, 3 T.C.M. 121 (1944) (capital or ordinary gain question). These cases were under the 1939 Code prior to its' amendment by the Revenue Act of 1942 (considered at page 115 infra). The same rule was followed after that Act (e.g., Leland Hazard, discussed at page 117 infra).

${ }^{21}$ Where property is inherited or purchased for rental purposes, merely listing it with an agent for "sale or rent" will qualify it as trade or business property for purposes of classifying a loss on sale as ordinary rather than capital. Mary E. Crawford, 16 T.C. 678 (1951); N. Stuart Campbell, 5 T.C. 272 (1945) (acquiesced, 1946-1 Cum. Bull. 1). This cannot be accomplished by merely listing the property for "sale." Maria Assman, 16 T.C. 632 (1951). But abandoned residential property must actually be rented to achieve a conversion to trade or business use, and the renting must indicate a real intent to devote the property to the production of rental income. E. R. Fenimore Johnson, 19 T.C. 93 (1952); Charles F. Neave, 17 T.C. 1237 (1952).

2256 Stat. 798 (1942).

${ }^{23}$ E.g., 53 Stat. 12 (expenses) and 14 (depreciation) (1939) (\$\$23(a) and (1), Int. Rev. Code of 1939 as originally passed).

24 See page 113 supra.

$\approx$ E.g., George S. Jephson, 37 B.T.A. 1117 (1938), and cases cited note 20 supra.

${ }^{28} 312$ U.S. 212 (1941).
} 
dollars) was not engaged in a trade or business. Expense deductions of $\$ 150$,000 were disallowed. The Court ruled: "whether the activities of a taxpayer are 'carrying on a business' requires an examination of the facts in each case."27 For this purpose it seems difficult to justify a distinction between a taxpayer who invests in securities and one who invests in rental properties. If the activities of one demand examination in making the trade or business determination, so should those of the other.

But the Higgins Court not only laid down a rule; by its application of the rule it appears to have altered the scope of activities which theretofore had been considered trade or business. The Court stated:

The petitioner merely kept records and collected interest and dividends from his securities, through managerial attention for his investments. No matter how large the estate or how continuous or extended the work required may be, such facts are not sufficient as a matter of law....28

If Higgins' extensive activities in employing persons for record keeping, collecting income, and managing securities were not a trade or business, then serious doubt is cast on the proposition that a landlord who rents a single dwelling is, without further activity, in a trade or business. It appears that here the Court set a precedent for examining closely the extent of the "business" activities of a taxpayer who would use that category, and in so doing also narrowed the scope of the category "trade or business" as it had previously been understood and applied. This left an area within which taxpayers engaged in income producing activities could not deduct the expenses arising therefrom.

Legislation to correct this inequity came in the Revenue Act of $1942 .{ }^{29} \mathrm{~A}$ section of that Act $^{30}$ passed in response to the Higgins case, ${ }^{31}$ created a new category-"production of income"-within which the taxpayer was allowed

$\approx$ Ibid., at 217 .

${ }^{28}$ Tbid., at 218 .

${ }^{2}$ See note 22 supra.

${ }^{30}$ Section 121, Revenue Act of 1942, 56 Stat. 798 (1942).

${ }^{31}$ This has been repeatedly recognized by the courts. E.g.: "This amendment was proposed . . . to afford specific relief for a specifically defined inequitable situation which had become manifest by the decision of the Court in Higgins $v$. Commissioner. . . "McDonald v. Comm'r, 323 U.S. 57, 61 (1944). Speaking before the House while explaining this portion of the bill, Representative Disney of the Ways and Means Committee said: "Trade or business has received such a narrow interpretation that many meritorious deductions are denied. [Citing and explaining the Higgins case.] Since the income from such investments is clearly taxable it is inequitable to deny the deduction of expenses attributable to such investments. To cure this inequity the bill contains a provision. . ." 88 Cong. Rec. 6,376 (1942). Similar statements appear in committee reports: Report of the Committee on Ways and Means on H.R. 7378, 77th Cong. 2d Sess. 46, 74 (1942); Report of the Senate Committee on Finance on H.R. 7378, 77th Cong. 2d Sess. 87 (1942). 
expense and depreciation deductions. ${ }^{32}$ In the words of Mr. Justice Black, "The language it utilized was certainly far broader than was required to meet the narrow problem presented by the Higgins case."33

It appears that Congress intentionally made this new class broader than was required by the specific inequity in the Higgins case. ${ }^{34}$ Securities are not subject to depreciation. If Congress had thought that the Higgins case narrowed the definition of trade or business only as to investors in securities, there would have been no need to enact any provisions allowing depreciation on "property held for the production of income."35

By virtue of the Higgins case and the Revenue Act of 1942, the pre-1942 category of trade or business appears to have been transformed into two classes: a new and narrower trade or business class, and a production of income class. Rental activities which were in the pre-1942 trade or business category might now fall in either of the new classes. ${ }^{36}$ A close examination of a taxpayer's rental activities would therefore seem essential in order to place him in the correct classification.

It may be inferred from the 1943 Treasury Regulations elaborating on the 1942 amendments that some, and perhaps all, rental activities were thought by the Treasury Department to be within the new production of income class. The regulations under "Business Expenses" make no reference to deductions attributable to rental property; ${ }^{37}$ but under the title "Nontrade or Nonbusiness Expense" regulations were published with regard to:

${ }^{32} \mathrm{An}$ individual is allowed as deductions: "all the ordinary and necessary expenses paid or incurred during the taxable year-(1) for the production or collection of income; (2) for the management, conservation, or maintenance of property held for the production of income. . . " Int. Rev. Code $\$ 212$. Section 167 provides a depreciation deduction for "property held for the production of income."

${ }^{33}$ Black, J., dissenting in McDonald v. Comm'r, 323 U.S. 57, 67 (1944).

${ }^{34}$ It is significant that Representative Disney explained the Higgins case in this manner: "expenses in connection with a taxpayer's investments in income-producing properties were not deductible on the grounds that making casual investments was not a trade or business." 88 Cong. Rec. 6,376 (1942). Thus the problem presented to the House was broader than merely that security holders were denied expense deductions; rather the whole class of income-producing properties (including of course rental properties) is characterized as imperiled by the Higgins decision.

${ }^{35}$ Int. Rev. Code $\S 167$.

${ }^{36}$ That these are two distinct classes, and that rental activities may fit into either one is demonstrated in Section 62 of the Code. That section defines adjusted gross income as gross income, less enumerated deductions, including trade or business deductions and deductions attributable to the production of rents and royalties. From the inclusion of both these classes, it seems that the drafters of Section 62 felt that expenses attributable to the production of rents or royalties might be allowable under either the trade or business category or the production of income category.

${ }^{37}$ Treas. Reg. 111, $\$ 29.23(\mathrm{a})-1$ (1943); unchanged in Treas. Reg. 118, $\$ 39.23(\mathrm{a})-1$ (1953). 
expenses incurred in the management, conservation, or maintenance of a building devoted to rental purposes. . . .38

and

expenses paid or incurred in connection with the management, conservation, or maintenance of ... rental property. ...39

A different Treasury Regulation brought on by the 1942 amendments and likewise presenting the question of the meaning of "trade or business" was before the Tax Court in Leland Hazard. ${ }^{40}$ This case offered the Tax Court its first opportunity to consider the effect of the Higgins decision and the Revenue Act of 1942 on its mechanical rule that renting, without further activity, was a trade or business. The taxpayer there sought the trade or business label for his rental activities so that the loss on sale of his single rental dwelling would be an ordinary loss. The government in arguing for a capital loss cited ${ }^{41}$ this regulation dealing with capital assets to establish that now rental property was not necessarily to be considered trade or business property:

Property held for the production of income, but not used in a trade or business of the taxpayer, is not excluded from the term "capital assets" even though depreciation may have been allowed with respect to such property under section 23(1) prior to its amendment by the Revenue Act of 1942.42

Since the only property on which depreciation was allowed prior to the Revenue Act of 1942 was trade or business property, ${ }^{43}$ the clear implication of the Regulation was that the old definition of trade or business property had been narrowed; that property which used to be trade or business property could now be either property held for the production of income, or trade or business property. 44

Under the Treasury Department's view, the old trade or business authorities would then be of dubious value. A court dealing with a trade or business issue, such as that involved in the Hazard case, would have to decide whether

${ }^{3}$ Tbid., at $\S 29.23(\mathrm{a})-15(a)(2)$ and $\S 39.23(\mathrm{a})-15(\mathrm{~b})$.

${ }^{30}$ Treas. Reg. 111, $\S 29.23(\mathrm{a})-15(b)$ (Supp., 1946); unchanged in Treas. Reg. 118, $\$ 39.23(\mathrm{a})-15(\mathrm{~h})$ (1953).

107 T.C. 372 (1946) (acquiesced, 1946-2 Cum. Bull. 3).

4 Ibid., at 376.

42 Treas. Reg. $111 \$ 29.117-1$ (1943); unchanged in Treas. Reg. 118, $\$ 39.117$ (a)-1(b) (1953).

${ }^{2}$ See note 23 supra.

"The regulation was criticized in a note at 59 Harv. L. Rev. 119 (1945) as an unjustified intrusion on the established concept of trade or business. The author, however, overlooked the Higgins case and its effect in narrowing that concept. It is instructive that the court in Leland Hazard cites this note (at page 376), apparently adopting its view. At the opposite extreme one critic has argued that all rental activities should be in the production of income category. Roehner, Tax Court in Error in Holding All Rental Property is "Used in Trade or Business," 83 J. of Accountancy 477 (1947) ; reprinted in 25 Taxes 1000 (1947). 
the ownership and rental of a single rental dwelling was still a trade or business, within the narrowed definition, or whether it was now merely the "production of income." But the Hazard court did not undertake to re-evaluate the question. Relying on its old trade or business precedents, the court merely stated:

The property here, however, was "used in the trade or business of the taxpayer." The [above] quoted regulation, by its terms, specifically excludes such from its purview. .5

In this fashion the precedent was set which prevails in the Tax Court today: that a taxpayer who rents a single dwelling, ${ }^{46}$ or piece of unimproved land, ${ }^{47}$ is without further inquiry engaged in a trade or business.

This easily applied rule has won some adherents outside the Tax Court, 48 the most significant being the seventh circuit in its recent (1955) decision in Reiner $v$. United States. ${ }^{49}$ There a taxpayer who engaged in no activities with regard to her single rental dwelling was held, for purposes of the loss carryover provision, ${ }^{50}$ to be in a trade or business. But fuller consideration of that case will be deferred, since it is more meaningful when viewed in the light of the opposite rule, as set forth in earlier federal cases.

For the most part, the federal district and appellate courts ${ }^{51}$ have followed

${ }^{45} 7$ T.C. 372,376 (1946).

"Anders I. Lagreide, 5 CCH Tax Ct. Rep. 53,035, 23 T.C. No. 62 (1954) (carryover, $\$ 172$ ) ; Ellsworth F. Ireland, 10 T.C.M. 430 (1951) (deductibility of loss on sale, $\$ 165$ ); Claude P. Noble, 7 T.C. 960 (1946) (deductibility of expenses, $\$ 162$ ) ; M. T. Thomas, 5 T.C.M. 805 (1946) (classification and deductibility of loss on sale, $\$ \$ 1221,165$ ).

${ }^{4}$ John F. Good, 16 T.C. 906, 909 (1951); cf., Solomon Wright, 9 T.C. 173 (1947). Contra: Susan P. Emery, 17 T.C. 308 (1951), where the court, citing no cases, held that unimproved waterfront property which had been rented from 1928 to 1942 and sold in 1944 at a loss by the trust of which the taxpayer was a beneficiary, was not used in the trade or business. The Emery case appears to have been an off-breed case. It has not been relied upon in the Tax Court, which attempted to distinguish it in Almy Gilford, 11 T.C.M. 175 (1952) on grounds that "the property was not improved and the owners permitted its sale for delinquent taxes." (Ibid., at 176).

${ }^{t 3}$ Rothschild v. Berliner, 50-2 U.S.T.C. 13,431 (N.D. Cal., 1950).

222 F. 2d 770 (C.A. 7th, 1955).

${ }^{50}$ Int. Rev. Code of $1939 \$ 122$, the predecessor to present Section 172.

${ }^{61}$ Gilford v. Comm'r, 201 F. 2d 735 (C.A. 2d, 1953), where the court sustained a taxpayer's contention that his extensive rental holdings constituted a trade or business (for purposes of classifying a loss as ordinary or capital) because of the "necessarily regular and continuous activity" involved in managing his property and supplying services to the tenants (Ibid., at 736.); Durbin v. Birmingham, 92 F. Supp. 938 (S.D. Iowa, 1950) ; Rogers v. United States, 69 F. Supp. 8 (D. Conn., 1946). Cf., Pinchot v. Comm'r, 113 F. 2d 718 (C.A. 2d, 1940), and the ninth circuit's standard in Comm'r v. Boeing, discussed note 19 supra. Smith v. Gallagher, 52-2 U.S.T.C. 46,235 (S.D. Ohio, 1952) is sometimes cited for the proposition that renting of a single dwelling is not a trade or business. The residence was rented by a testamentary trust until the tenant vacated. Then the taxpayer 
the procedure used by the sixth circuit in Fackler $v$. Commissioner, ${ }^{52}$ examining the extent of a taxpayer's rental activities in determining whether he is in a trade or business. The second circuit recently (1955) applied this test in Grier v. United States. ${ }^{53}$ The taxpayer in that case had suffered a loss on the sale of his single rental dwelling. Under the Code provisions then in effect a loss on the sale of such trade or business property was not available for operating loss carryover. ${ }^{54}$ To gain a capital loss carryover the taxpayer argued that his had not been trade or business property. After carefully examining his rental activities, the court sustained this contention, stating:

In this case the activities with relation to this single dwelling, although of long duration, were minimal in nature. Activity to rent and re-rent was not required. No employees were regularly engaged for maintenance or repair. Lacking the broader activity55 ... the real estate in this case appears to partake more of the nature of property held for investment than property used in a trade or business..$^{56}$

The court went on to say that the property was used in the production of income.

A direct conflict between the circuits on this point was first created by Reiner v. United States, ${ }^{57}$ in which case the seventh circuit, by following the Tax Court view, rejected the second circuit's Grier approach. The taxpayer in the Reiner case was attempting to recover taxes paid in the years 1943 to 1946 inclusive. Her single rental dwelling in Vienna, Austria, had been severely damaged in a bombing raid in 1944. She asserted that this loss was "attributable to the operation of a trade or business regularly carried on"58

withdrew the property and sold it at a loss. The court found that the trust and the taxpayer were "separate entities for the purpose of computing income taxes." (Tbid., at 46,237.) There was no evidence that the property had been rented or even offered for rent while in the taxpayer's hands. The court's holding that it was not trade or business property therefore could hardly be authority for the proposition that the renting of a single dwelling is not a trade or business.

${ }^{52}$ Discussed at page 113 supra.

120 F. Supp. 395 (D. Conn., 1954), aff'd on the opinion below 218 F. $2 d 603$ (C.A. $2 d$, 1955).

st Int. Rev. Code of $1939 \$ 122$, discussed in note 9 supra.

w The court here cited the Gilford and Pinchot cases, supra note 51, and Fackler v. Comm'r, discussed at page 113 supra.

so 120 F. Supp. 395, 398 (D.Conn., 1954), aff'd on the opinion below 218 F. 2d 603 (C.A. 2d, 1955).

5722 F. 2d 770 (C.A. 7th, 1955).

$\$$ Int. Rev. Code of $1939 \$ 122$. The 1954 Code ( $\$ 172)$ allows carryover when the loss is "attributable to a taxpayer's trade or business." As this is a less rigorous requirement than that of the old Code, the Reiner decision should be applicable a fortiori to a similar case under the new Code. 
and so could be carried back and forward to the years in question. ${ }^{59}$ Due to the war the taxpayer had received no rents from her property and from her residence in Chicago had, of course, engaged in no activities with regard to the rented property.

The government reviewed this lack of rental activity, and then cited the Grier case in support of its contention that this loss was not subject to carryover. $^{60}$ In reply, the taxpayer's brief contended that the Grier case was distinguishable. ${ }^{61}$ The basis of distinction urged was that Grier involved the definition of "trade or business" within the meaning of the predecessor of Section 1221 (definition of capital assets), ${ }^{62}$ while the problem in the Reiner case was whether the rental property was used in the "trade or business" within the meaning of the forerunner of Section 172 (carryover). ${ }^{63}$ The brief did not explain why this made any difference, but hastened on to cite a Tax Court decision $^{64}$ dealing with the precise problem of "trade or business" for loss carryover purposes. There the Tax Court, following its well-established rule, had held that rental of a single residence was a trade or business. ${ }^{65}$

Although there was no authority for distinguishing the meaning of "trade or business" as used in the two sections, the distinction argued appears to have been accepted by the seventh circuit. The Grier case is not mentioned in the opinion, and the Tax Court's loss carryover decision ${ }^{66}$ was the only authority cited for the proposition that this taxpayer was engaged in a trade or business.

The Grier and Reiner cases are not to be distinguished by saying that they involved different sections of the Code. The Grier case held that a single rental dwelling was not property "used in the trade or business." The Reiner case held that a casualty loss sustained on a single rental dwelling was "attributable to the operation of a trade or business regularly carried on." Since this loss undoubtedly was "attributable to the operation" of the rented property,

${ }^{59}$ After December 31, 1950, all casualty losses, whether or not incurred in trade or business, were subject to carryover. Int. Rev. Code of 1939 (as amended) $\$ 122$.

${ }^{\infty 0}$ Brief for Appellant at 14.

o1 Brief for Appellee at 17.

E2 Int. Rev. Code of 1939 § 117 (a).

${ }^{e s}$ Ibid., at $\$ 122$.

ss Anders I. Lagreide, 5 CCH Tax Ct. Rep. 53,035, 23 T.C. No. 62 (1954).

${ }^{65}$ What the brief did not point out was that in that case (note 64 supra), though the problem was loss carryover (predecessor to Section 172 of the Code), the Tax Court relied exclusively on decisions (such as Leland Hazard, discussed at page 117 supra) having to do with the classification of loss on the sale of rental property (predecessor to Section 1221 of the Code). Apparently the Tax Court was of the view that "trade or business" has the same meaning for either of these purposes.

${ }^{\infty}$ See note 64 supra. 
which operation was "regularly carried on," the only question in the Reiner case was whether the operation of a single rental dwelling was a trade or business-the same question as that dealt with in the Grier case. Because the rental activities in Reiner were at least as insignificant as those in Grier, the contrariety of result can be explained only on the basis of different standards having been applied.

Such a conflict destroys uniformity in the administration of the tax law in an area of significance to the small landlord. The historic absence from the Code of a "trade or business" definition ${ }^{67}$ probably indicates a continuing reluctance to define the term. But legislation of a more modest scope ${ }^{68}$ should suffice to resolve this conflict and put taxpayers on the same basis in the determination of their trade or business status whether they invest in real property or securities. A section which provided that in the case of an individual, the ownership of rental property shall consist of a trade or business only where the taxpayer carries on a significant degree of activities in its management, operation, and maintenance ${ }^{69}$ should be adequate. Such a provision would require a uniform use of the procedure used by the second circuit: an examination of the extent of a taxpayer's rental activities in making the trade or business determination.

"In the American Law Institute's proposed Federal Income Tax Statute, the comparable term, "business" (compare X 227 with Code $\$ 1221$ ), is defined in this manner: "BUSINESS includes profession, vocation, trade, or employment." (Ibid., at $X$ 12.) Such a definition probably would not include the activities of a taxpayer with a single rental dwelling unless significant enough to constitute a "vocation" or "trade," categories rather difficult to reach on the basis of the operation of a single rental dwelling.

There is one precedent for piecemeal legislation on the trade or business problem. Congress has made one specific inclusion: "The term 'trade or business' includes the performance of the functions of a public office." (Int. Rev. Code $\$ 7701$ [26]).

${ }^{\infty}$ Such a section would, however, involve a difficulty of interpretation where a taxpayer had more than one piece of rental property. The taxpayer's rental activities might be considered as a whole, and where the requisite activity was present all of his property be considered trade or business property. This extreme would avoid the difficulties inherent in trying to classify various pieces of a taxpayer's rental property, but it might be unfair to force upon a taxpayer who holds properties both for trade or business use and for investment such an "all or nothing" interpretation. At the opposite extreme, the requisite degree of activity might be required with regard to each piece of property, a lengthy job of proof where rental holdings are large. Between these two extremes is a better solution. The taxpayer's activities could be considered as a whole to determine whether or not he is in a trade or business as to the whole. Then, whatever the determination, either of the litigants could go forward to rebut this determination as to selected pieces of the taxpayer's property. Such an approach is similar to the privilege extended by the Code to dealers in securities, who may establish that securities normally held for sale to customers are investments (capital assets) by complying with certain requirements including segregation ( $\$ 1236$ ). Although subject to additional requirements, the dealer in real estate can obtain a similar privilege under court decision. (E.g., Nelson A. Farry, 13 T.C. 8 [1949].) Such an interpretation, under which a taxpayer with large rental holdings could segregate his property and hold it for various purposes, would make the proposed provision workable in its application to any taxpayer with rental holdings. 